\title{
Nigeria University Education and the Challenges of Attaining Sustainable Development Goals (SDGS)
}

\author{
Silas Onuche Joel, PhD \\ Shehu Mustapha Liberty, PhD \\ Department of Public Administration, P M B 1069, University of Maiduguri, Maiduguri, Borno State, Nigeria
}

\begin{abstract}
University education plays a crucial role in the attainment of Sustainable Development Goals (SDGs) agenda launched by the United Nations Organization (UNO) in the year 2015. In the light of the quality university education in Nigeria, this paper assesses the effect of quality university education on the attainment of SDGs, which are meant to be achieved by the year 2030. Relying on secondary data through the adoption of system theory, the paper discusses the state of university education in Nigeria, its effect on national development as well as on the realization of the SDGs. The paper found that there is poor delivery of quality university education with proclivity to global low ranking. The paper amongst others suggest for increase in regional and global partnership on university education to boost scholarship, Information and Communication (ICT) application and curriculum development which are imperative in attaining high standard of excellence in university education.
\end{abstract}

DOI: $10.7176 / \mathrm{EJBM} / 11-23-02$

Publication date: August $31^{\text {st }} 2019$

\section{Introduction}

Sustainable Development Goals (SDGs) also known as 2030 Agenda for Sustainable Development is a global Agenda initiated by the United Nations Organization (UNO) as a framework through which countries of the world particularly in Africa, Least Developed Countries (LDCs), landlocked developing countries and small island developing states of the world can attain the level of development that lasts for a long time. The SDGs is made up of seventeen (17) goals and one hundred and sixty nine (169) targets that cut across all facets of development as it relates to earth inhabitants.

One of the important goals as encapsulated in Goal four (4) of the Agenda is ensuring inclusive and equitable quality education and promote lifelong learning opportunities for all. The pursuit of quality education is a major tool for national socio-economic political development as well as individual socio-economic empowerment and poverty reduction. The educational system is vital because it produces the personnel that are required to function in various facets of national life and development process (Polycarp and Gimba, 2010). In the same vein, Joel, Abba and Babagana (2018) noted that higher education provides the platform for personal and societal advancement in social, moral, economic, cultural and technological areas of life.

The provision of quality higher education through the tertiary institutions particularly the university education is germane to the realization of the SDGs. The university education is relevant not only in advancing the frontiers of knowledge at socio-economic, political and technological fronts but also in producing as well as training the requisite personnel for the realization of entire SDGs which are integrative and overlapping. Eneanya (2015) succinctly noted that university education serves the purpose for the advancement of human welfare through the enlargement and communication of knowledge in the spirit of free enquiry. At its best, university education frees individual minds as it develops competence for the higher pursuits in life. It widens the horizons of the nation's judgment while supplying skills essential to the nation's tasks.

\section{Statement of the Problem}

Aggressive pursuit and attainment quality higher education is vital to the realization of SDGs in Nigeria. However, the quality of higher education delivered in Nigerian universities in recent years has been an issue of concern to the government, corporate organizations, international organizations and indeed other stakeholders in Nigeria society. This becomes glaring based on the rating and ranking of Nigerian university from the global point of view. At the higher level of education, the $37^{\text {th }}$ General Conference of UNESCO held in October 2013 while observing an increase in access was grossly dissatisfied with the quality of university graduates. Similarly, it is observed that Nigerian university is not among the top one hundred (100) best universities in the world and also not among the top four (4) in Africa according to times Higher Education world universities Ranking 2018 (http://www.premiumtimes.com). In the ranking, the universities were graded in core areas like teaching research, knowledge transfer and international outlook. This low rating of Nigerian universities becomes worrisome because it smacks of the quality, standard and relevance of higher education delivery in the Nigerian universities. Furthermore, Akinnnaso (2017) while lamenting on the state of education at higher level in Nigeria noted that the situation could not have been worse for Nigeria than now when the major indicators of quality university education are at their lowest levels leading to the production of poor quality graduates, who are being advised by the 
government to go to farm in the absence of job opportunities and some of those who don't want to go to the farm take various forms of crime, including robbery, kidnapping and cybercrime. This paper therefore investigates the trends, causes and consequences of the lower quality of higher education delivered in Nigerian universities and its effect on the realization of SDGs.

\section{Objectives of the Paper}

The objectives of this paper are to;

i. identify the causes of poor delivery of university education in Nigeria;

ii. assess the consequences of poor quality university education on national development; and

iii. examine the implication of poor quality university education on the realization of SDGs.

\section{Briefs on Nigerian University Education}

The quest for higher education in Nigeria predates the colonial era. Eneanya (2015) accounted that the beginning of higher education in Nigeria dates back to the time of the abolition of slave trade in England, in 1772 and the resettlement of these freed slaves in Freetown (the capital of Sierra-Leone). The first known Nigerian to receive some form of higher education was Samuel Ajayi Crowther who was one of the last slaves sold in West Africa and repatriated to Freetown in 1822. The Fourah Bay College in Sierra Leone was founded by the Church Missionary Society in 1827 to train ministers, teachers and day workers for the church. Ajayi returned from England to become the first registered student of the new college. This institution was affiliated to the University of Durham in Ireland. Samuel Ajayi Crowther and his brother ex-slave Henry Carr became the first graduates of this college. The institution opened the way to higher education of students from all former British colonies in West Africa (i.e Nigeria, Gambia, Sierra Leone and Ghana) and from the inception of the college from 1827 to 1950, more than $50 \%$ of Fourah Bay students were Nigerians.

The demand for establishment of universities in Nigeria were growing strong and stronger owing to many factors which are: the request by the nationalists, the need to reduce the stress and sufferings of Nigerians who trooped to Europe, America and other places outside Nigeria to acquired university education, the need to have institutions that conduct researches to extend the frontier of knowledge as well as the need to provide high quality graduates for the industries and economy at large which was in very short supply during that period.

The University College Ibadan (UCI) was established in 1948, as a corollary of nationalists demand as the Yaba Higher College, which was established in Lagos before then, was very different from a university. As a result of population explosion and the need to offer relevant programmes in other field of human endeavor, University of Nigeria, Nsukka (UNN) and University of Lagos were later established in 1960 and 1962 respectively. As Nigeria continues to grow in population and structure, which led to the creation of many states, the number of Universities continues to increase. As at late 2017, Nigeria has 153 Universities made up of Federal, States and Private owned Universities. These Universities aim at providing higher education. The National Policy of Education Section 5, subsection 32 (1981:22) as cited in (Eneanya 2015:207) stated the goals of higher education thus;

i. the acquisition, development and inculcation of the proper value orientation for the survival of the individual and the society;

ii. the development of intellectual capacities of individuals to understand and appreciate their environment;

iii. the acquisition of both physical and intellectual skills which will enable individuals to develop into useful members of the community; and

iv. the acquisition of an objective view of the local and external environment.

Higher educational institutions especially the universities are to pursue these goals through teaching, research, dissemination of existing and new information, the pursuit of service to the community and serving as a storehouse of knowledge.

\section{Briefs on SDGs}

The SDGs is a plan of action for people, plants and prosperity. It is also referred to as the 2030 Agenda for Sustainable Development. The SDGs contain seventeen (17) inspirational goals and one hundred and sixty nine (169) targets between them as a post 2015 Development Agenda as documented at (www.un.org/sustainabledevelopmentgoals). These goals are summarized as:

Goal 1: End poverty in all its forms everywhere

Goal 2: End hunger, achieve food security and improve nutrition and promote sustainable agriculture

Goal 3: Ensure healthy lives and promote well-being for all at all ages

Goal 4: Ensure inclusive and equitable quality education and promote life- long learning opportunities for all

Goal 5: Achieve gender equality and empower all women and girls

Goal 6: Ensure availability and sustainable management of water and sanitation for all

Goal 7: Ensure access to affordable, reliable, sustainable and modern energy for all 
Goal 8: Promote sustained, inclusive and sustainable economic growth, full and productive employment and decent work for all

Goal 9: Build resilient infrastructure, promote inclusive and sustainable industrialization and foster innovation

Goal 10: Reduce inequality within and among countries

Goal 11: Make cities and human settlements inclusive, safe, resilient and sustainable

Goal 12: Ensure sustainable consumption and production patterns

Goal 13: Take urgent action to combat climate change and its impacts

Goal 14: Conserve and sustainably use the oceans, seas and marine resources for sustainable development

Goal 15: Protect, restore and promote sustainable use of terrestrial ecosystems, sustainably manage forests, combat desertification, and halt and reverse land degradation and halt biodiversity loss

Goal 16: Promote peaceful and inclusive societies for sustainable development, provide access to justice for all and build effective, accountable and inclusive institutions at all levels

Goal 17: Strengthen the means of implementation and revitalize the Global Partnership for Sustainable Development. It is imperative to note now that the SDGs has direct and indirect connection with provision of quality university education. In other words, provision of quality university education is key to the actualization of the goals. The goal four (4) of the SDGs focuses mainly on education: it goes thus:

"Ensure inclusive and equitable quality education and promote life- long learning opportunities for all"

In order to attain this goal, certain targets were set in relation to it. These targets are by 2030 to:

i. ensure that all girls and boys complete free, equitable and quality primary and secondary education leading to relevant and effective learning outcomes

ii. ensure that all girls and boys have access to quality early childhood development, care and pre-primary education so that they are ready for primary education

iii. ensure equal access for all women and men to affordable and quality technical, vocational and tertiary education, including university

iv. substantially increase the number of youth and adults who have relevant skills, including technical and vocational skills, for employment, decent jobs and entrepreneurship

v. eliminate gender disparities in education, ensure equal access to all levels of education and vocational training for the vulnerable, including persons with disabilities, indigenous peoples and children in vulnerable situations

vi. ensure that all youths and a substantial proportion of adults, both men and women, achieve literacy and numeracy

vii. ensure that all learners acquire the knowledge and skills needed to promote sustainable development, including, among others, through education for sustainable development and sustainable lifestyles, human rights, gender equality, promotion of a culture of peace and non-violence, global citizenship and appreciation of cultural diversity and cultures contribution to sustainable development:

vii(a) Build and upgrade education facilities that are child, disability and gender sensitive and provide safe, non-violent, inclusive and effective learning environment for all;

vii(b) By 2020, substantially expand globally the number of scholarships available to developing countries, in particular least developed countries, small island developing states and African countries, for enrolment in higher education, including vocational training and information and communication technology, technical, engineering and scientific programmes, in developed countries and other developing countries; and,

vii(c) By 2030, substantially increase the supply of qualified teachers, including through international cooperation for teacher training in developing countries, especially least developed countries and small island developing states.

The realization of goal four (4) and indeed other goals of SDGs require delivery of quality university education.

\section{Theoretical Framework}

This paper adopts system theory. There are different perspectives of system theory such as the Input-ThroughputOutput (Eastonian), Cybernetics and Organismic perspectives. The organismic perspective of system theory will form the basis for explaining university education and SDGs in this write up. The organismic perspective is an attempt to study and understand an organization, a policy, programme or an entity as a living organism. A system is meant to achieve a particular goal and is dependent upon the effective functioning of its parts called sub-systems. Each sub-system performs a series of needed activities.

Dlakwa (2009) expresses that in this respect, a system is seen as analogous to a living organism that is maintained and sustained by its internal components. Using anatomical features as a basis of illustration, he explains that all the anatomical features that perform vital functions are developed in the organism such as the heart, brain, eyes and ears. These organs must work in harmony to enable the organism put effective resistance 
against pressures exerted on it by exogenous forces. Through homeostatic adjustment process, the organism can continue to cope with the periodic disturbances from the environment. In other words, the survival of the organism depends on the extent to which it can maintain a form of dynamic equilibrium with the ever-changing environment in which it operates.

When this theory is applied to the Nigeria University Education and the attainment of SDGs, the university education is viewed as a component of the entire education system, which is categorized into basic or primary education, secondary and tertiary education. Similarly, the university education is part of the Goal (4) of the SDGs and for the goals to be attained, the delivery of quality university education should be ensured. This is because it is connected to other levels of education in Nigeria.

\section{Causes of Poor University Education in Nigeria}

There are myriads of the causes of poor delivery of university education in Nigeria. These include poor funding, depreciating quality of teachers, research capacity deficit, inadequacies in facilities for teaching, learning, and research, lack of regional quality assurance framework and accreditation system and slow adoption of ICT for delivering quality higher education (Jegede, 2017). It is pertinent at this juncture to briefly explain some of these points mentioned.

Poor funding: Finance plays major role in the delivery of quality education at the university level. The input through men and materials in order to obtain a desirable quality output can only be mobilised, organized and accomplished through proper funding. However, successive governments in recent times in Nigeria have not demonstrated high commitment to quality university education through funding. This among other areas is obvious in the percentage of annual budget allocated to education sector. Budgetary allocation to the education sector as a whole has not been very encouraging. Nigeria budgetary allocation to the sector has been on the decrease from $10 \%$ to $6.24 \%$ between 2015 to 2017 as reflected in Table 1.1 below:

Table 1.1 Nigeria Education Budget 2013 - 2017

\begin{tabular}{|l|l|l|l|}
\hline Year & $\begin{array}{l}\text { Allocation to Education } \\
\text { Sector (In Billions of N) }\end{array}$ & $\begin{array}{l}\text { National Annual Budget } \\
\text { In(Trillions of N) }\end{array}$ & $\begin{array}{c}\text { \%o of Annual Budget } \\
\text { Allocation to Education } \\
\text { Sector }\end{array}$ \\
\hline 2017 & $455,407,788,565$ & $7,298,507,709,937$ & 6.24 \\
\hline 2016 & $480,278,214,688$ & $6,077,680,000,000$ & 7.90 \\
\hline 2015 & $483,183,784,654$ & $4,493,363,957,158$ & 10.75 \\
\hline 2014 & $495,283,130,268$ & $4,642,960,000,000$ & 10.67 \\
\hline
\end{tabular}

Source: //www.budgetoffice.gov.ng

The Nigerian 2018 annual budgetary allocation to the education sector is not different form the low percentages reflected in Table 1.1. Out of 9.1 (Nine point one trillion naira) approved as a national budget only a paltry sum of 102.907 (billion naira) representing 7\% was allocated to the education sector which is expected to cater for about 40 Federal Universities, 28 Federal Polytechnics, 21 Federal Colleges of Education, 104 Federal Unity Schools as well as 28 parastatals. All these budgetary allocations over the years were grossly inadequate and fall short of UNESCO standard, which stipulated that $15 \%-20 \%$ of National budget should be allocated to education. Needless to say that these low allocations has profound effect on quality of education.

Depreciating quality of teachers: it is axiomatic that no quality education can be obtained above the quality of the teachers. The quality of teachers at university level has been depreciating with many of them unable deliver a wellresearched lecture note nor write implementable research proposal due to lack of basic skills in research methodology. Some present papers they cannot defend due to plagiarism. As a result, there are not well equipped to teach the undergraduates qualitatively. This no doubt affects the quality of graduates being produced negatively. Research capacity deficit: It is no longer secret that some university teachers lacks requisite research skills and are unable to write an implementable research proposal due to lack of basic skills in research methodology. Some lecturers also present papers they cannot defend due to plagiarism. Jegede (2017) reveals to support the reality of this ugly trend when he noted the quality of research proposals submitted to Tertiary Education Trust Fund (TetFund) by mostly university lecturers for funding. In assessing the research proposals for funding support, less than 40 percent of the proposals are readable while only 15 percent of these readable ones are successful. The overall consequences of this is that innovation and technology that ought to grow from research and development at university level is stunted thereby defeating one of the very essence of university education which is to promote research and development.

Inadequate Teaching Facilities: Meaningful teaching can only take place at university level where relevant facilities for teaching, learning and research are available in right quantity and quality. It is obvious that facilities like libraries, laboratory equipment and machines, vehicles, offices for teachers and hostels for students, recreational facilities are not only in short supply but are not in good condition. In addition, it also limits the number of students that can be admitted into higher institutions. Jegede (2017) stressed this point when he noted 
that the phenomenal stress on universities as a result of pressure for admission is so enormous. On the average between the year 2010 - 2016, out of over 1.5 million Nigerians seeking admission to tertiary institutions, only about $26.5 \%$ are successful. This is because facilities in the higher institutions particularly the universities are overstretched. This makes teaching and learning cumbersome. The deficiencies of most of these facilities in addition to poor staff welfare have been the major causes of strike actions by university teachers in Nigerian universities. The cumulative effect of these infrastructural inadequacies is that effective knowledge necessary for empowerment cannot be imparted unto the students.

Lack of regional quality assurance framework and accreditation system: The control of the content and quality of teaching and learning at university level is key to sustaining academic standard. Regular monitoring of academic service delivery has not been very effective by relevant committee, and agencies. In addition, review of curriculum and the entire content of studies to meet the ever-changing needs of the society have also not been quiet timely. Academic accreditation exercises in universities are sometimes compromised thereby making some universities to run courses that they obviously have not resources and requirements to run. This hampers quality of university education.

Slow adoption of ITC for delivering quality higher education: The influence and impact of Information and Communication Technology (ITC) in modern teaching and learning across the global is tremendous. Hence for universities to catch up with the ever increasing demand for quality education, the use of ICT at faster rate need to be applied both in lecture delivery, conduct of examination and conduct of research. The rate of application in teaching and learning at university level has been very slow on the part of both the teachers and the learners. Electronic instruments for ICT based learning are not sufficient and sustainable on various university campuses. On the part of the learners or students, it not easy to get for instance a personal computer (laptop) due to poverty. This affects and obstructs free and speedy sharing of knowledge for quality education at university level with the consequence of poor delivery of university education.

\section{Consequences of Poor Delivery of Higher Education on National Development}

Education is key to national development and for all sectors to develop adequately there must be abundance of well-developed human capital to power them through university education. On the contrary, the poor delivery of university education as witnessed in Nigeria in this era has debilitating effect on national development. These effects can be viewed from the following dimensions:

Poor Quality of Human Resource Development: Educational institutions particularly the universities remain relevant training institutions for the production and development of manpower. However, the declining state of the quality of university education has resulted in the production of poor quality of manpower for various sectors of the economy. In some critical activities like oil and gas exploration, expatriates are being engaged because of non- availability or incompetency of indigenous personnel to undertake such activities. This makes these critical industrial activities to be under the control of foreign influence that may undermine national interest.

Educational Tourism: The poor quality of university education in Nigeria has resulted in mass exodus of Nigerian students to foreign countries where quality university education is delivered compared to what is obtainable in Nigeria. The search for quality university education and stable academic calendar has propelled many Nigerians to go to foreign countries like USA, UK, Germany, France, Malaysia, India and even some African countries like Ghana, Kenya and South Africa. The tuition fees and other expenses of these Nigerian students are paid in the currency of their host countries thereby leading to drain of Nigerian currency, which affect national income, and by extension economic growth.

Brain Drain: It is no longer strange that the poor quality of university education has led to migration of Nigerian lecturers and technocrats to other countries. In most cases, these lecturers and technocrats are experts and highly experienced in their various field of specialization. Their exist are normally replaced by mediocre who offer low rate of services to the educational sector thereby leading to further decline in quality of university education delivered. In most cases the half -baked graduates are absorbed into the education sector and this lead to recycling of mediocre who neither possess the required skills and knowledge to formulate quality educational policy nor the experience to implement it.

Enthronement of Neocolonialism: Inadequate and lack of competent professionals and expertise occasioned by poor quality of university education has given expatriates strategic positions in various spheres of national life as contractors and consultants. This makes economic independence far from being a reality as their actions and inactions furthers the interest of their home countries who may be interested in perpetrating their economy hegemony of developing countries like Nigeria. All these frustrate national efforts at attaining true development.

\section{Effects of Poor Quality of University Education on the Attainment of SDGs}

The SDGs is meant to launch nations of the world to higher realm of development by the year 2030. As earlier noted, there exist a nexus between quality of education and national as well as global development. Therefore, the poor delivery of university education could have a profound adverse effect on the attainment of SDGs in the 
following ways:

Impediments to Industrial Growth: Industrial growth and development is directly linked to the attainment of SDGs. For instance, goal 12 (twelve) of the SDGs aims at ensuring sustainable consumption and production patterns. Similarly, goal 9 (nine) focuses on building resilient infrastructure, promote inclusive and sustainable industrialization and foster innovation. These goals require sustained research at university level of education to attain them. It is a known fact that most inventions and innovations in all fields of human endeavors across the world are carried out at the level of university education research. And this innovation is catalyst to industrialization and economic growth. Poor delivery of university education will undermine the attainment of industrial production and industrialization related goals of the SDGs.

Difficulty in Handling Unemployment: Providing productive employment opportunities is one of the cardinal objectives of the SDGs. It is important to create employment opportunities but also very necessary to produce employable graduates. The poor quality of university education consequently produce half-baked that are largely not employable. Some graduates are jobless because of the quality of education they received which cannot make them to get job or create job. Joblessness results in lack of income which deepens poverty in all its forms everywhere.

Complication in Realizing Educationally Related Goals: It take quality university education to realize other educationally related goals like SDGs 4 and 5 which deals with provision of inclusive quality education and gender equality and empowerment for women and girls respectively. The university is a production hub of quality teachers necessary for the formulation and implementation of quality policy for the realization of basic education. Poor quality of university education negatively affects the quality and quantity of teachers for the implementation of Universal Basic Education (UBE) scheme. This hampers the realization of educationally related goals of SDGs. From the aforementioned points and analysis, it is incontrovertible that poor quality of university education delivery has proclivity to retrogressive effects on the attainment of SDGs by the year 2030. There is therefore strong need to take steps to improve quality of university education delivery.

\section{Conclusion}

University education is a catalyst to socio-economic and political development of any nation including Nigeria. However, from the discussion in this paper, the state of university education calls for urgent improvement to strengthen its quality on a solid footing to serve as a lunch pad to the attainment of national and global development.

\section{Recommendations}

The following recommendations are hereby offered to improve the quality of university education as key to the attainment of Sustainable Development Goals (SDGs).

i. Increase in Government Funding: The role of government in the delivery of quality university education is still critical in Nigeria. There is a need to consolidate on this role through increase in budgetary allocation to the education sector. The civil society organizations can assist in the performance of this function by embarking on peaceful means of mounting pressure on government as well as monitoring and tracking spending by relevant educational agencies and institution of government.

ii. Increase in Private Sector Contributions and Participation: The need for increase in private sector contributions and participation in the provision and delivery of quality university education is important because they are also consumers of university products and graduates. Private and corporate organizations should be encouraged to contribute more funds to the education sector through education tax while those who are interested in running private university could be granted opportunities after meeting the requirements and with government ensuring proper monitoring and evaluation to avoid abuse and decline in the quality delivered.

iii. Increase in Parental roles and Responsibilities: The home through the parents also needs to play a revitalizing role in improving the quality of university education. The parents should ensure that their wards imbibe good morals that discourage cheating and other negative vices and extolling dignity of labour and honest work. They should also strive to discharge their responsibilities to ensure that their wards lack no fund and other resources necessary for them to excel in university education.

iv. Strengthening Global Partnership: The need for regional and global partnership on university education as it relates to ICT scholarship and curriculum development is imperative. This to enable Nigeria strives toward attaining high standard of excellence is the delivery of quality university education.

\section{References}

Akinnaso, N. (2017). "University Education in Nigeria at the Cross Roads" https://punch.com/University Education in Nigeria retrieved $02 / 11 / 2018$.

Budgetary Allocation to Education Sector (2018) at//www.budgetoffice.gov.ng retrieved 09/01/2018

Dlakwa, H. D. (2009). Concepts and Models in Policy Formulation and Analysis: Kaduna: Pyla-Mak Service Ltd. 
Eneanya, A.N. (2005). Theory and Practice of Public Administration: University of Lagos, Nigeria: University of Lagos Press and Bookshop Ltd.

Jegede, O. (2017). Quality of University Education in Nigeria: The Challenge of Social Relevance: A Paper delivered at the $22^{\text {nd }}$ and $23^{\text {rd }}$ Combined Convocation Ceremony of University of Uyo, Nigeria.

Joel, S. O. Abba, B. L. and Babagana, A. (2018). "Enhancing Effective Resources Utilization in Nigerian Public Universities through New Public Management (NPM) Strategy in Journal of Public Policy Administration Research Vol. 8, No. 9, Pp. 17 - 23.

Nigeria University Rankings (2018) Quality of Higher Education in Nigeria https:www.Premiumtimes.com/news/286731 retrieved 02/11/2018.

Polycarp, I.M. and Gimba, Z. (2010) "Global Economic Meltdown and the Nigerian Educational System" in Journal of Peace, Security, Human Rights and Development in the $21^{\text {st }}$ Century by Joel P. Dada, A. Sa'ad and A. Muazu (eds) : Vol. 2 Pp. 163 - 184, A Publication of Centre for Peace, Diplomatic and Development Studies, University of Maiduguri.

SDGs of the UNO (2016) at www.un.org/sustainabledevelopmentgoals retrieved 05/01/2016. 